DOI https://doi.org/10.18551/rjoas.2018-03.14

\title{
THE INFLUENCE OF VARIETY ADAPTATION AND STAKE INCLINATION ANGLE ON THE GROWTH, RESULT AND CONVERSION EFFICIENCY OF SWEET POTATO (IPOMOEA BATATAS L.) IN BALIEM VALLEY, PAPUA HIGHLAND
}

\author{
Soplanit Alberth* \\ Graduate School of Agriculture, Faculty of Agriculture, Brawijaya University \& \\ Indonesia/Papua Assessment Institute for Agricultural Technology, Indonesia \\ Guritno Bambang, Ariffin, Suminarti Nur Edy \\ Faculty of Agriculture, Brawijaya University, Indonesia \\ *E-mail: asoplanit@yahoo.co.id
}

\begin{abstract}
Sweet potato (Ipomoea batatas L.) is a plant that needs full sun to grow and get optimum yield. It needs an engineering technology that is able to integrate plant and environment in order to overcome abiotic factors in Papua highland. This research aims to determine the growth, result and energy conversion efficiency conatined in the sweet potato by combining variety and different stake inclination angle. This research was conducted in Baliem valley of Jayawijaya district. The experimental design used was factorial group random design with three replications. The research result shows that to make plant more efficient in managing solar intensity in Papua highland, so it is advised to plant Cangkuang variety (broad leaf) and to use stakle with inclination angle of $60^{\circ}$ and $90^{\circ}$.
\end{abstract}

\section{KEY WORDS}

Sweet potato, variety, stake inclination, Papua highland, conversion efficiency.

Papua and West Java are two regions with the largest sweet potato harvested area in Indonesia, while for the side of production level. West Java's sweet potato production is higher than Papua. Rauf and Lestari (2009) reported that the variety of Papua Sollosa, Papua Pattipy and Sawentar in Papua highland are harvested at 6 months old with the production of 24-25 t ha-1. Furthermore, Saraswati et al. (2013) reported that Papua Pattipy, Papua Sollosa and Cangkuang planted in Baliem valley at 6 months old resulted in 20.78, 14.68 and $13.28 \mathrm{t} \mathrm{ha}^{-1}$ respectively. In west java, the varieties planted are SQ-27, Ceret, Cilembu and Prambanan with 4-5 months old, their production is 25-30 $\mathrm{t} \mathrm{ha}^{-1}$. This result indicates that the production of sweet potato in Papua is still low, let alone the production potential is $30 \mathrm{t} \mathrm{ha}^{-1}$ on average. Agatha and Takeda's research result (1982) in Japan can reach $40 \mathrm{t} \mathrm{ha}^{-1}$ with solar radiation $339 \mathrm{cal} \mathrm{cm}^{2}$ day $^{-1}$ and the average temperature is $24.2^{\circ} \mathrm{C}$.

Most of sweet potato farmer in Papua stay in agroecosystem area of highland (Limbongan and Soplanit, 2007). Abiotic factor as higher level clouds is a limiting factor of the low harvested result of sweet potato in Papua highland. Farmer at Baliem valley has a hereditary local wisdom to addapt sweet potato cultivation by growing long spiral-shaped cultivar in the middle of allotment land and crept up vertically using stake as well as short spiral-shaped cultivar is grown as egde plants (Wydiastuti, 1994). All of those efforts are intended to position leaf so that able to receive low solar intensity so that the harvested result of sweet potato is higher. Soenarto (1997); Saraswati et al., 2013 report that the intencity of solar radiation in Baliem valley is relatively slow and only about $1.38 \mathrm{KJ} \mathrm{cm}^{2} \mathrm{day}^{-1}$ and the average of sunshine duration is 3.98 hours day $^{-1}$. In reality, sweet potato needs at leas 10 11 hours of sunshine to achieve maximum photosynthesis rate (Ravi, 2003; Ravi and Saravanan, 2012).

There have been so many studies on sweet potato at Baliem valley like the one conducted by Widyastuti, 1994; Soenarto, 1997 and Saraswati et al., 2013. However, almost all those studies only focus on the socio-culture aspect of the dani people in managing sweet 
potato and studying agronomical aspect. While the study on the respond of plant to the abiotic factors as the result of higher level clouds is not conducted yet. For that matter, in order to make sweet potato more efficient in managing low solar radiation in Baliem valley, it is made an engineering technology by choosing variety having proper morphology as well as positioning leaf so that the angle is more vertical to receive sunshine. Therefore, it is expected the photosynthesis rate is more enhanced and the harvested result in form of carbohidrate is also storage more. According to Wargiono (1980), most of broad-leaved sweet potato is able to conduct photosynthesis effectively; the result is higher than the variety of narrow leaf or fingered leaf. Maryasa (1990) concludes that stake usage makes plant able to catch light efficiently and decrease the effect of shading each other so that the light can be distributed proportionally to all parts of leaf.

This research aims to test the respond of veriety and morphology of narrow leaf, medium leaf and broad leaf as well as different stake inclination angle that can increase plant ability to take advantage of solar radiation efficiently. As an assessment of how big the availability of plant efficiency to manage solar radiation intensity in Papua highland can be measured from the harvested result, dry matter production and energy conversion efficiency during the growth period of sweet potato.

\section{MATERIALS AND METHOD OF RESEARCH}

A field study was conducted at Wesakin village, Wouma subdistrict, Jayawijaya district, Papua, Indonesia, (138 $.57^{\prime}$ East longitude, $04^{\circ} 04^{\prime}$ south longitude, $1560 \mathrm{~m}$ above sea level) during the planting season in April until September 2016. On dry land with soil type of entisol, soil texture is sandy loam and the $\mathrm{pH}$ is 5.2. This research uses three varieties of sweet potatoe: Siate (local), Papua Sollosa (improved variety) and Cangkuang (improved variety).

An experiement to use factorial group random design is conducted in three replications. Variety of factor $A$ is made up of three types: Siate (V1) represents narrow leaf, Papua Sollosa (V2) represents medium leaf and Cangkuang (V3) represents broad leaf. Four different stake inclination angles as factor $B$ are made up of using no stake (A0), stake angle $45^{\circ}$ (A1), stake angle $60^{\circ}(\mathrm{A} 2)$, and stake angle $90^{\circ}$ (A3). Soil was managed using a special scoope; the land was divided into three groups and each of then was divided again into 5.25 $\times 6.50 \mathrm{~m}$ plot. The distance between the groups is $100 \mathrm{~cm}$ and the distance between the plot is $50 \mathrm{~cm}$, while the planting distance is $75 \times 50 \mathrm{~cm}$, every one cutting is planted in a whole of single mound. Hand weeding was conducted at the 15, 45, and 80 day after planting (DAP). Fertilizer application and pest control chemically are not conducted since there is chemical prohibition of usage for agriculture by the local government. Observation was conducted destructively by taking sample of two plants that were not the edge plant at 40,70,100, and 130 days or the observed parameter at everry observation. Sample taking was conducted by harvesting sweet potato using stake or local people cal it sege. Interception of solar radiation was measured above and under canopy at 11 a.m when the wheather is bright using $\mathrm{LX}$ $1330 \mathrm{~B}$ meter lux. A set of measurement was conducted 3 times above the cannopy and 3 times on the surface soil. The data of global solar radiation was gained from Wamena meteorology station class 3 .

Table 1 - Climate condition in Baliem Valley, Wamena

\begin{tabular}{ccccc}
\hline Observation Period & $\begin{array}{c}\text { Average air } \\
\text { temperature } \\
\left({ }^{\circ} \mathrm{C}\right)\end{array}$ & $\begin{array}{c}\text { Average soil } \\
\text { temperature } \\
\left({ }^{\circ} \mathrm{C}\right)\end{array}$ & $\begin{array}{c}\text { Average solar } \\
\text { radiation } \\
\left(\text { Cal.cm }^{-2} \text { hari }^{-1}\right)^{\star}\end{array}$ & $\begin{array}{c}\text { Average rainfall } \\
(\mathrm{mm})^{\star}\end{array}$ \\
\hline 2 April - 12 May & 21.00 & 25.00 & 113.28 & 131 \\
\hline 13 May - 13 June & 20.00 & 23.00 & 99.31 & 98 \\
\hline 14 June - 14 July & 19.00 & 23.00 & 117.02 & 97 \\
\hline 15 July - 15 August & 19.00 & 23.50 & 107.43 & 67 \\
\hline Average & 19.75 & 23.63 & 109.26 & 98.25 \\
\hline
\end{tabular}

Source: * = Wamena meteorology station class III 
Observation variables include total leaf, plant dry weight, harvested result and energy convertion efficiency. Total leaf was counted of all leaf been opened perfectly on a two plant sample. Total sweet potato was counted entirely at every plot and divided by total plant during harvesting season. While the energy conversion efficiency uses a method developed by Yoshida (1981). Part of plant was separated into root, stem, leaf and tuber, and then dried in an oven until reach the weight constant with temperature of $80^{\circ}$. Plant dry weight wa counted by adding all parts of plant that has been dried in an oven. Photosyntesis efficiency was measured based on the total dry weight $\left(\mathrm{g} \cdot \mathrm{m}^{-2}\right)$ divided by solar radiation accumulative $\left(\mathrm{cal}^{-2}\right.$ days $\left.^{-1}\right)$ after harvesting.

Statistics analysis was conducted using Analisis Varians (ANOVA) at $5 \%$ significance level. The difference between treatmen that was tested using Duncan Multiple Range Test (DMRT) 5\%. Analysis data was conducted buing Genstat 17 statistic program and Microsoft Office Excel program 2010.

\section{RESULTS OF STUDY}

Leaf number. Sweet potato plant was conducted after the end of el nino long dry season in 2015 at midle montana area, Papua. The average time of 8.25 hours sunshine is $66-69 \%$, solar radiation intensity of 150 DAP is $20,661.90 \mathrm{cal} \mathrm{cm}^{-2}$ day $^{-1}$ (unpublishe data). The development of total sweet potato leaf planted after the end of long dry season indicates the first real difference of growth until 130 DAP. Total leaf increases at all treatment conditions following plant development and reaches the highest number at V1A0 treatment condition at $100 \mathrm{DAP}$, it tends to decrease at $130 \mathrm{DAP}$ until approaching harvesting season. The lowest leaf umber is gained at a combination of V1A3 treatment. the high number of leaf during the V1A0 treatment combination is influenced by Siate characteristic having longer sucker than other varieties and approcing ground so that getting nutrient to maintain the leaf longer. In opposite way, V1A3 treatment experiences a decrease since the appearence of new surculus is not balances with the number of dried leaf. The relationship between variety treatment combination and stakle inclination angle to the leaf number parameter are demonstrated in (Figure 1).

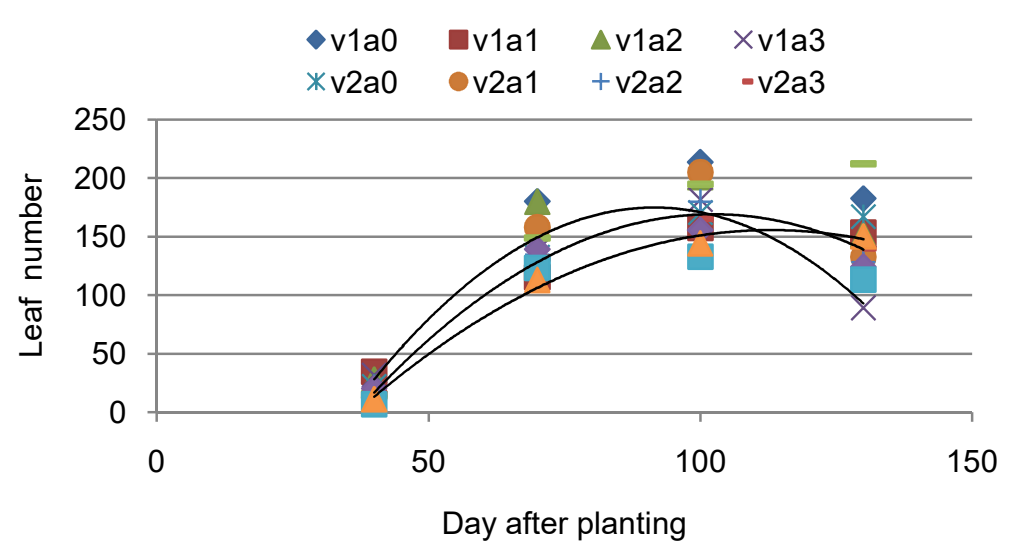

Figure 1 - The relationship between variety combination and stakle inclination angle with leaf number of sweet potato of local Siate variety (a), Papua Sollosa (b) and Cangkuang (c). Polynomial model for

Siate, Papua Sollosa and Cangkuang variety is V1y $=-0.0553 \times 2+10.127 x-288.43, R^{2}=0.9793$;

$V 2 y=-0.0393 x 2+8.0302 x-241.55, R^{2}=0.998$ dan $V 3 y=-0.0267 x 2+6.0344 x-185.4$, $\mathrm{R}^{2}=0.9918$ respectively.

Plant dry weight. The influence of variety treatment combination and stakle inclination angle on the total dry weight indicates significant difference at all phases of growth excluding vegetative phase at 40 DAP. The highest dry weight is gained from V3A3 treatment combination at 130 DAP (326.9 $\mathrm{g} \mathrm{plant}^{-1}$ ) (Figure 2). Cangkuang leaf morphology that is relatively broad with vertical inclination angle truly influences the ability of leaf to catch solar 
radiation. The higher the solar radiation catch, the higher the photosyntesis rate so that the assimilate resulted in form of dry matter is high. This result can explain that the intensity of solar radiation is a more dominant factor in increasing biomassa production to actuate metabolism activity and pant genetical characteristic. Gifford et al. (1984); Adeboye et al. (2016) states that in a field condition, plant development depends on the canopy capacity to intercept radiation incident and change it into new biomassa. Total radiation incident intercepted depends on the index of leaf area and canopy orientation. Leaf area index is influenced by leaf number and leaf area covering canopy. Furthermore, Plenet et al. (2000) concludes that Photosynthetically Active Radiation (PAR) absorbed by canopy depends on the LAI and plants leaf structure.

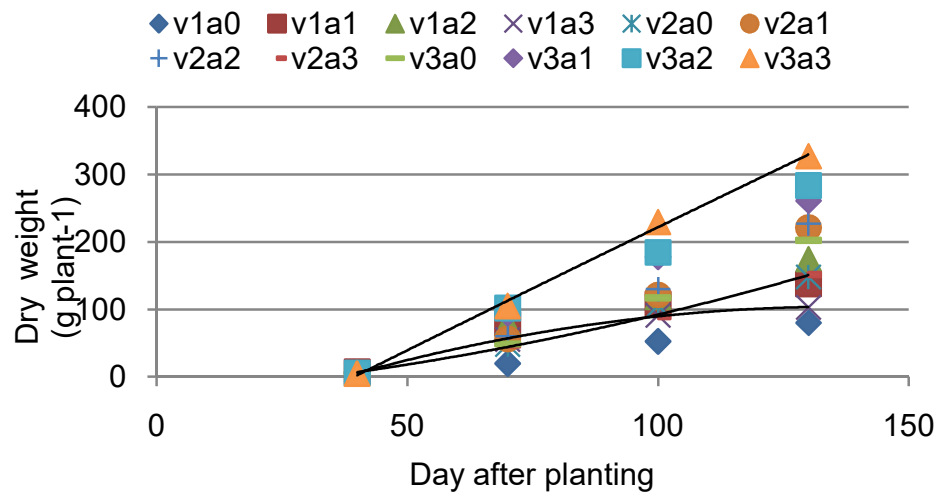

Figure 2 - The relationship between variety combination and stakle inclination angle to the total dry weight of sweet potato. Polynomial model for Siate variety (a), Papua Sollosa (b) and Cangkuang (c) respectifully is $y=-0.0104 \times 2+286.14 x-92.246, R^{2}=0.9989 ; y=-0.0059 x 2+0.5938 x-26.281$, $\mathrm{R} 2=0.9984$ dan $y=0.0008 x 2+37.661 x+147.08, R 2=0.9978$

Tuber yield. Variance analysis result of the number of tuber and marketable tuber proportion during harvest of $150 \mathrm{DAP}$ is presented in (Table 2). Variety treatment combination and stakle inclination angle is not significantly different to the number of tuber. Type of sweet potato variety has a significant influence $(p<0.05)$ on the tuber number per plant. On average, the highest tuber number gained from Cangkuang variety is 3.68 and the lowest is gained by Papua Sollosa and local variety by 3.08 and 2.72 tubers respectively. Stakle inclination angle has a significant influence $(p<0.05)$ on the tuber number per plant. It is obvious that the variety with broader leaf and stakle uses is able to increase tuber number per plant. The highest tuber number is gained from stakle inclination angle $45^{\circ}$ and $60^{\circ}$ by 3.70 and 3.28 respectively, but not significantly different with stakle angle $90^{\circ}$ (3.11) (Table 2).

Table 2 - The average influence of variety combination and stakle inclination angle on the tuber number/plant and marketable tuber (\%)

\begin{tabular}{|c|c|c|}
\hline \multirow{2}{*}{ Treatment } & \multicolumn{2}{|c|}{ Average number of tuber and marketable tuber } \\
\cline { 2 - 3 } & Number of tuber/plant & Marketable tuber (\%) \\
\hline Variety & - & - \\
\hline V1 (Siate) & $2.73 \mathrm{a}$ & $42.78 \mathrm{a}$ \\
\hline V2 (Papua Sollosa) & $3.08 \mathrm{a}$ & $39.50 \mathrm{a}$ \\
\hline V3 (Cangkuang) & $3.68 \mathrm{~b}$ & $52.25 \mathrm{~b}$ \\
\hline Stakle angle & - & $36.52 \mathrm{a}$ \\
\hline A0 (without using stakle) & $2.57 \mathrm{a}$ & $50.09 \mathrm{~b}$ \\
\hline A1 (Stakle angle 45 $45^{\circ}$ & $3.70 \mathrm{~b}$ & $51.08 \mathrm{~b}$ \\
\hline A2 (Stakle angle $60^{\circ}$ ) & $3.28 \mathrm{~b}$ & $41.68 \mathrm{ab}$ \\
\hline A3 (Stakle angle $90^{\circ}$ ) & $3.11 \mathrm{ab}$ & \\
\hline
\end{tabular}

Note: The number followed by different letter in the same column indicates significant difference at Duncan test $(p=0.05)$. 
Sweet potato variety has a significant influence $(p<0.05)$ on the marketable tuber proportion, it is obvious that the highest total marketable tuber is Cangkuang variety by $52.25 \%$ higher than Papua Sollosa and local Siate variey by $42.78 \%$ and $39.50 \%$ respertively. The influence of stakle angle is significantly different $(p<0.05)$ to the total marketable tuber, the highest total marketable tuber is at the stakle angle $60^{\circ}$ and $45^{\circ}$ by $51.08 \%$ and $50.09 \%$ but not significantly difference with stakle angle $90^{\circ}(41.68 \%)$. This result can explain that the use of variety with broad leaf and stakle use is able to increase marketable tuber proportion. The relationship between tuber number and marketable tuber proportion is demonstrated in (Figure 3a).

Variance analysis yield to the sweet potato yield of 150 DAP is presented in Figure $3 \mathrm{~b}$. Combination of variety treatment and stakle inclination angle to the parameter result of sweet potato indicates significance different $(p<0.05)$ and ranges between $12.60-31.53 \mathrm{t} \mathrm{ha}^{-1}$. The highest result of tuber is ganed from the combination of V3A3 and V3A2 by $31.53 \mathrm{t} \mathrm{ha}^{-1}$ and $28.86 \mathrm{t} \mathrm{ha}^{-1}$ repectively. The increase treatment of stakle inclination angle of those three varieties can increase sweet potato result, excluding V1A3 and V2A3 treatment, tends to decrease result. The lowest result of sweet potato is gained from the combination of $\mathrm{V} 1 \mathrm{~A} 0$, $\mathrm{V} 1 \mathrm{~A} 3$ and V2A0, V2A3 treatment.

The number of tuber, marketable tuber proportion, tuber yield is a parameter that can represent the result (Table 2 and Figure 3b). Low sunshine condition in Baliem valley, Papua highland enables Cangkuang variety to have more efficient leaf morphology in getting solar radiation, as indicates by the higher tuber number of sweet potato and marketable tuber proportion compared to other varietes. An efficiency of catching solar radiation is also influenced by stakle inclination angle treatment since the leaf position is more vertical to the solar system direction. This also influences tuber number per plant and marketable tuber proportion is higher than the tretament without using stakle. This matter is inline with Maryasa (1990) opinion that stakle use makes plant able to catch sunlight more efficiently. Moreover, Oswald and Midmore (1995) states that sweet potato shaded will curate an innitiation of tuber structuring, number of tuber and size tuber.

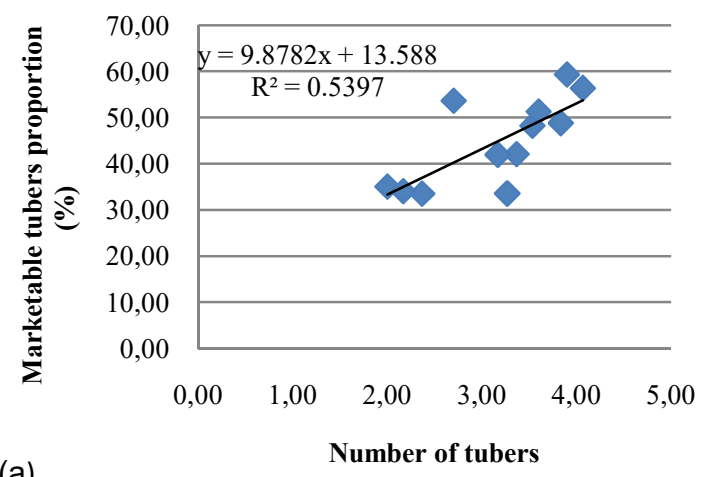

(a)

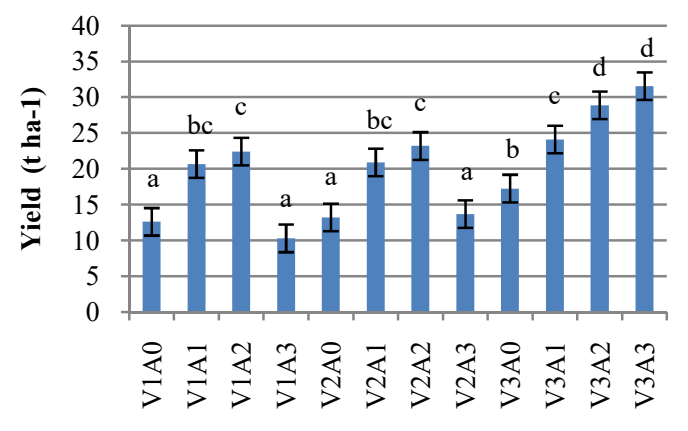

(b)

Treatments combination

Figure 3 - The relationship between number of tuber per plant and marketable tuber proportion. The linear model is $y=9.8782 x+13.588, R^{2}=0.5397, r=0.7346$

It appears that the combination of sweet potato varieties especially broad-leaved varieties with increasingly higher stakle inclination angle makes the location of the leaves more vertical, in low conditions, sunshine enables most leaf sheets to capture light for photosynthesis. While the combination treatment of varieties without using stakle causes only the upper leaf sheet that receives light while the leaves on the bottom layer lacks light because it shades and affects the low net photosynthesis results. The low yield of sweet potato on the combination of $\mathrm{V} 1 \mathrm{~A} 3$ and $\mathrm{V} 3 \mathrm{~A} 3$ treatments is due to the fact that some leaves of the photosynthesis agent dried up. 


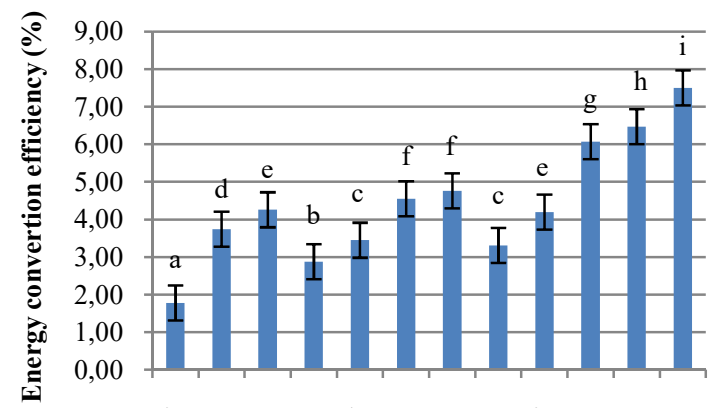

s.5.

(a)

Treatments combination

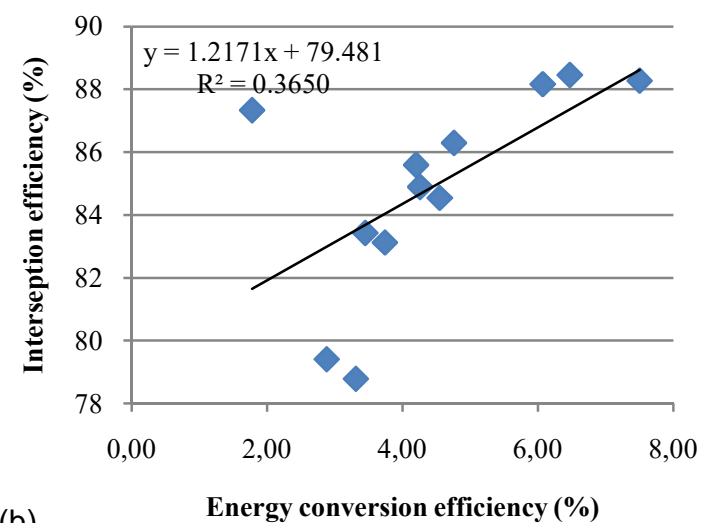

(b)

Energy conversion efficiency $(\%)$

Figure 4 - The relationship between the interception efficiency (Ei) and the energy conversion efficiency $(E C)$ of sweet potatoes in the combination of variety treatment and the stakle inclination angle, the line in the figure is an estimation of linear model $y=1.2171 x-79.481, R 2=0.3650$, correlation coefficient value, $r=0.6041$

Interception efficiency (Ei) and Energy conversion efficiency (EC). Varieties treatment was significantly different $(p<0.05)$ on the interception radiation efficiency $(E i)$. Variance result analysis of efficiency parameter of solar radiation shows that Cangkuang variety produces the highest Ei compared to Papua Sollosa and local Siate varieties, which is $87.62 \%, 83.68 \%$ and $83.26 \%$ respectively (Figure $4 \mathrm{~b}$ ). When viewed from the aspect of efficiency interception, it shows that Cangkuang variety having broad-leaved morphology more efficient in catching incoming PAR radiation compared to Papua Sollosa and Siate whose leaf is medium and narrow. The combination of variety treatment and the angle of inclination was not significantly different from the interception efficiency parameter.

The sweet potato grown in Papua highland with solar intensity for 150 days of $20,661.90 \mathrm{cal} \mathrm{cm}^{-2}$ day $^{-1}$ produces energy conversion efficiency (EC) of $1.78-7.50 \%$. The highest EC values were obtained in a combination of $\mathrm{V} 3 \mathrm{~A} 3$ treatment by $7.50 \%$, while the lowest EC was obtained in a combination of $\mathrm{V} 1 \mathrm{~A} 0$ treatment by $1.78 \%$ (Figure $4 \mathrm{a}$ ). The amount of EC is influenced by the high production of dry matter to PAR which falls on the canopy. The result of energy conversion efficiency is high because conversion efficiency for root crop, according to Rana and Rana (2014) is 1.6 - $1.9 \%$. The relationship between interception efficiency and energy conversion efficiency is shown in (Figure 4b).

Based on the estimation of sun position from hour angle to the stakle inclination angle, it indicates that the perpendicular position of the sunlight for stakel angle $90^{\circ}$ falls at 12 a.m, the perpendicular position of the sunlight for stakle angle $60^{\circ}$ falls at 10 a.m and the perpendicular position of sunlight for stakle angle $45^{\circ}$ falls at 9 a.m (data not shown). The average sun exposure in Baliem valley starts at 10 a.m, before that the sunlight is still covered with clouds and fog. This data explain that the sweet potato gets full sun angle at 10 a.m to 12 a.m, and it occurs at the $90^{\circ}$ and $60^{\circ}$ stakle angles. Fujise and Tsuno (1962) states that the rate of photosynthesis of sweet potato shows a cycle with a specific pattern during normal susnshine periods, that is high radiance in the morning until afternoon and then getting low again. Moreover, it is said that in the subtropical zone, net photosynthetic rate is about $12 \mathrm{mg} \mathrm{CO}_{2} \mathrm{dm}^{-2}$ hour ${ }^{-1}$ between at 9 a.m - 1 p.m, then decrease until hingga $2 \mathrm{mg} \mathrm{CO}_{2}$ $\mathrm{dm}^{-2}$ hour $^{-1}$ at 5 p.m.

Thus, it can be concluded that the interception and the use of solar radiation is influenced by genetic factors and plant environment and both of them interact with each other. In addition to the leaf morphological characteristic that affects plant physiological response, inclination angle position of leaf toward the arrival of sunlight becomes the determinant factor of the number of energy conversion efficiency of sweet potato. Goudriaan (2016) states that the distribution of leaf angle plays an important role in determining the interception of light. In the absence of water and nutrient shortages, the efficiency of solar radiation is determined by light interception, especially PAR by canopy and patterns of light 
distribution in plant canopy (Monteith, 1977; Sitaniapessy, 1985; Russell et al., 1989; Tesfaye et al. 2006).

\section{CONCLUSION}

Dry matter production increase is influenced by leaf number increase influencing the broad of leaf area. Leaf morphology and the inclination angle interact each other in increasing plant dry matter, tuber yield and energy conversion efficiency of sweet potato. Morphological form of leaf characterized by broad leaf truly influences the high efficiency of radiation interception causing number of tuber and marketable tuber proportion enhancement. Separately, stakle inclination angle influences the high number of tuber per plant and marketable tuber proportion. Due to the low condition of solar radiation intensity in Papua highland, variety with broader leaf together with more vertical stakle inclination angle interact ecah other to influence the high value of energy conversion efficienct of solar system. The combination of Cangkuang variety treatment and stakle angle $90^{\circ}$ results in highest EC by $(7.50 \%)$ compared to the combination of Siate variety treatment without using stakle $(1.78 \%)$.

\section{ACKNOWLEDGEMENTS}

This research is funded by Indonesian Agency of Agriculture and Development. Our appreciation is also for the project of ACIAR/SARDI/CIP/BPTP Papua, which have given grants for this research.

\section{REFERENCES}

1. Agata, W. And Tomoshiro Takeda, 1982. The characteristics of dry matter and yield production in sweet potato under field conditions. P.119-127. In R.L. Villareal and T.D. griggs (ed.) Proc. 1st int. Symp. Sweet Potato. AVEDC, Taiwan.

2. Adeboye. O.B, Bart Schultz, Kenneth O. Adekalu and Krishna Prasad (2016). Impact of water stress on radiation interception and radiation use efficiency of Soybeans (Glycine max L. Merr.) in Nigeria. Braz J. Sci. Technol (2016) 3:15.

3. Fujese, K. and Y. Tsuno, 1962. Study on dry matter production of sweet potato. I. Photosynthesis in the sweet potato with special reference to measuring of intact leaves under natural conditions. Proc.Crop.Sci.Soc.Japan 13:145-149.

4. Gifford RM, Thorne JH, Hitz WD, Giaquinta RT (1984). Crop productivity and photoassimilate partitioning. Science 225:801-808.

5. Limbongan, J., dan A. Soplanit. 2007. Ketersediaan teknologi dan potensi pengembangan ubijalar (Ipomoea batatas L.) di Papua. Jurnal Litbang Pertanian, 26 (4): 131-138.

6. Monteith, J.L. (1977). Climate and Efficiency of Crop Production in Britain. Philosophical Transactions of the Royal Society London B, 281, 277-294.

7. Maryasa, A. 1990. Pengaruh tinggi lanjaran dan waktu pemetikan sebagianpolong muda terhadap produksi dan viabilitas benih kacang panjang(Vigna sinensis (L.) Savi ex Hassk). Unpublished Thesis. Institut Pertanian Bogor.

8. Oswald, J., D.J. Alkaumper and I. Midmore, 1995a. Response of Sweet potato (Ipomoea batatas Lam.) to shading at different growth stages. Journal of Agronomy and Crop Science, 175: 99-107.

9. Plenet, D. A. Mollier, S. Pellerin (2000). Growth analysis of maize field crops under phosphorus deficiency. II. Radiation - use efficiency, biomass accumulation and yield components. Plant Soil 224:259-272.

10. Sitaniapessy PM. 1985. Pengaruh jarak tanam dan besarnya populasi tanaman terhadap absorbsi radiasi surya dan produksi tanaman jagung (Zea mays L.). Unpublished Dissertation. Bogor: Institut Pertanian Bogor. 
11. Russell, G., Jarvis, P.G., Monteith, J.L., 1989. Absorption of radiation by canopies and stand growth. In: Russell, G., Marshall, B., Jarvis, P.G. (Eds.), Plant Canopies: Their Growth, Form and Function. Cambridge University Press, Cambridge, pp. 21-40.

12. Ravi, V., 2003. Diurnal Changes in photosynthetic characteristics of sweet potato (Ipomoea batatas L.) Advanches and Horticultural Research 17, 159-164.

13. Rauf, A.W. dan M.S. Lestari. 2009. Pemanfaatan komoditas pangan lokal sebagai sumber pangan alternatif di Papua. Jurnal Litbang Pertanian, 28 (2): 54-62.

14. Ravi, V and Raju Saravanan. Crop physiology of sweetpotato (2012). Fruit, vegetable and cereal science and biotechnology. Global Science Books.

15. Rana, S.S. dan R.S. Rana. 2014. Advances in crop growth and productivity. Department of Agronomy, CSK HP Krishi Vishvavidyalaya, Palampur, India.

16. Soenarto, F. Rumawas, 1997. An agro-ecological analysis of wen - tinak, a sustainable sweet potato wetland production system in the Baliem Valley, Irian Jaya, Indonesia. Science in New Guinea 23 (2).

17. Saraswati, P., A. Soplanit., A.T. Syahputra, L. Kossay, N. Muid, E. Ginting and G.Lyons. 2013. Yield trial and sensory evaluation of sweetpotato cultivars in Highland Papua and West Papua Indonesia. Journal of Tropical Agriculture 51 (1-2): 74-83.

18. Tesfaye G, Sisay L, Dereje T, Abebe M and Solomon G 2006. Growth and reproductive performance of central highland goats in North Shoa and South Wollo. Proceeding of the first annual conference on completed livestock research activity organized in Bahir Dar, Ethiopia, 14-17 August 2006, 7-13.

19. Wargiono, J. 1980. Ubijalar dan cara bercocok tanamnya. LPP. Bul. Tek. No.5.

20. Widyastuti, C.A. 1994. Peranan wanita suku dani dalam mempertahankan kelangsungan ubijalar sebagai makanan pokok di Kabupaten Jayawijaya, Irian Jaya. Dalam risalah seminar penerapan teknologi produksi dan pasca panen ubijalar mendukung agroindustri. Balai Penelitian Tanaman Pangan Malang.

21. Yoshida, S. 1981. Fumandamentalis of Rice Crop Science. P.1-110. IRRI, Los Banos, Philipines. 